\title{
Penggunaan e-Money di Pelabuhan Internasional Sri Bintan Pura Tanjungpinang dalam Mendukung GNNT
}

\section{The Use of e-Money at Sri Bintan Pura Tanjungpinang International Port in Supporting GNNT}

\author{
Yeni Suseno ${ }^{1}$, Adji Suradji Muhammad², Edison ${ }^{3}$ \\ 1Universitas Maritim Raja Ali Haji - Tanjungpinang \\ 2Universitas Maritim Raja Ali Haji- Tanjungpinang \\ Email: yenisuseno@gmail.com
}

\begin{abstract}
ABSTRAK
Penelitian ini menggunakan pendekatan top-down model implementasi dari Van Meter dan Van Horn yang terdiri dari 6 variabel: (1) Standar dan tujuan kebijakan, (2) Sumber daya, (3) Komunikasi antar oganisasi terkait dan kegiatan-kegiatan pelaksanaan, (4) Karakteristik lembaga/ organisasi pelaksana, (5) Lingkungan Ekonomi, Sosial dan Politik, (6) Tanggapan/ Sikap Para Pelaksana. Jenis penelitian ini adalah penelitian deskriptif dan pendekatan penelitian menggunakan metode penelitian kualitatif. Teknik pengumpulan data ialah observasi, wawancara dan dokumentasi. Teknik pemilihan informan dalam penelitian ini menggunakan teknik Purposive Sampling untuk menentukan sampel penelitian dengan pertimbangan tertentu. Berdasarkan hasil penelitian Implementasi Kebijakan Gerakan Nasional Non Tunai Melalui Elektronic Money di Pelabuhan Internasional Sri Bintan Pura sudah terlaksana namun belum maksimal. Konsistensi dan koordinasi pihak pelaksana yang kurang maksimal dan sosialisasi yang belum mampu mengubah mindset masyarakat membuat banyak pengguna jasa masih menggunakan transaksi secara manual.

Kata Kunci: Implementasi Kebijakan GNNT, E-Money, Pelabuhan Internasional Sri Bintan Pura Tanjungpinang.
\end{abstract}

\section{ABSTRACT}

This study uses a top-down approach to the implementation model of Van Meter and Van Horn which consists of 6 variables: (1) Policy standards and objectives, (2) Resources, (3) Interorganizational communication and enforcement activities, (4) the characteristics of the implementing agencies/organizations, (5) Economic, Social and Political Conditions, (6) The disposition of implementors. This type of research is descriptive and the research approach uses qualitative research methods. Data collection techniques are observation, interview, and documentation. The technique of selecting informants in this study uses the purposive sampling technique to determine the research sample with certain considerations. Based on the results of research in Policy Implementation of the National Non-Cash Activity Via Electronic Money at Sri Bintan Pura Tanjungpinang International Port, it has been running but not maximally. The lack of consistency and coordination of the implementors and socialization that has not been able to change the people's mind-set has made many service users still use manuals transaction.

Keywords: The Policy of National Non-Cash Activity (GNNT), E-Money, Sri Bintan Pura Tanjungpinang International Port. 


\section{PENDAHULUAN}

Salah satu transportasi pilihan bagi masyarakat pulau adalah melalui jalur laut yakni melalui pelabuhan. Menurut Pasal 1 Undang-Undang No.17 Tahun 2008 Tentang Pelayaran, pelabuhan merupakan tempat yang terdiri atas daratan dan/atau perairan dengan batas-batas tertentu sebagai tempat kegiatan pemerintahan dan kegiatan pengusahaan yang dipergunakan sebagai tempat kapal bersandar, naik turun penumpang, dan/atau bongkar muat barang, berupa terminal dan tempat berlabuh kapal yang dilengkapi dengan fasilitas keselamatan dan keamanan pelayaran dan kegiatan penunjang pelabuhan serta sebagai tempat perpindahan intra-dan antarmoda transportasi. Sistem pembayaran dan pola bertransaksi ekonomi terus mengalami perubahan. Seiring dengan perkembangan teknologi yang pesat, pola dan instrumen pembayaran dalam transaksi ekonomi terus mengalami perubahan. Kemajuan teknologi dalam instrumen pembayaran menggeser peranan uang tunai sebagai alat pembayaran ke dalam bentuk pembayaran non tunai yang lebih efisien dan ekonomis.

Saat ini masyarakat memiliki banyak pilihan dalam melakukan transaksi. Salah satunya melalui metode konvensional dan modern. Dimana metode konvensional dilakukan menggunakan uang kartal, yakni uang kertas dan logam atau biasanya sering disebut sebagai uang tunai (cash). Sedangkan untuk kebutuhan keuangan masa kini, sudah banyak sekali teknologi yang dapat digunakan. Berkembangnya e-money misalnya, dengan adanya e-money berbagai transaksi modern dapat dilakukan.

Zaman seperti Generasi Z saat ini, kepraktisan merupakan hal yang sangat penting sehingga membawa masyarakat berevolusi dari penggunaan uang kartal sampai kemudian menjadi Less Cash Society. Khususnya dalam transaksi di pelabuhan, masyarakat di kenalkan dengan metode pembayaran baru non tunai yang dibuat oleh pemerintah. "Less cash society, secara harfiah dapat diterjemahkan sebagai masyarakat yang semakin sedikit memanfaatkan uang tunai dalam transaksi sehari-hari" (Jacobs, 2014). Secara tidak langsung pemerintah membentuk suatu komunitas atau masyarakat yang lebih menggunakan instrumen non tunai khususnya dalam melakukan transaksi atas kegiatan ekonominya.

Bank Indonesia mencanangkan program Gerakan Nasional Non Tunai pada tanggal 14 Agustus 2014. Gerakan ini dicanangkan dengan tujuan membentuk masyarakat yang lebih banyak menggunakan instrumen non tunai (Less Cash Society/LCS) dalam melakukan transaksi atas kegiatan ekonominya. Salah satu upaya perwujudan tujuan dari Gerakan Nasional Non Tunai adalah dengan mendukung dan mengembangkan uang elektronik sebagai instrumen pembayaran non tunai (Widyastuti et al., 2017).

Pelabuhan di Indonesia yang pertama kali mulai menerapkan penggunaan e-money yaitu Pelabuhan Internasional Sri Bintan Pura pada tahun 2018 di Kota Tanjungpinang. Pelabuhan tersebut merupakan salah satu pelabuhan yang dijadikan sebagai pilot project (tempat percontohan pelabuhan pertama) penggunaan e-money secara nasional (Nikolas, 2018).

Pemerintah melalui Gubernur Bank Indonesia (BI) mengeluarkan kebijakan GNNT melalui Peraturan Bank Indonesia Nomor 20/6/PBI/2018 tentang Uang Elektronik (electronic money/ e-money). Peraturan ini sudah mengalami lima kali revisi, mulai dari: (1) Peraturan Bank Indonesia Nomor 11/11/PBI/2009; (2) Peraturan Bank Indonesia Nomor 11/12/PBI/2009; (3) Peraturan Bank Indonesia Nomor 16/8/PBI/2014; (4) Peraturan Bank Indonesia Nomor 18/17/PBI/2016; (5) Peraturan Bank Indonesia Nomor 20/6/PBI/2018. Sebenarnya peraturan ini sudah lama berlaku sejak tahun 2009 di Indonesia dan baru diimplementasikan di Kota Tanjungpinang khususnya di Pelabuhan Sri Bintan Pura (SBP) pada tahun 2018.

E-money pada Pelabuhan Internasional SBP diklasifikasikan menjadi: Tiket Masuk Elektronik disebut electronic pass (e-pass), Jasa Tambatan Kapal berbasis online disebut e- 
berthing, dan Tiket Elektronik (e-ticketing) yang dikelola oleh masing-masing pihak di dalamnya. Dimana e-pass dikelola oleh PT. Pelindo bekerja sama dengan empat Bank meliputi Bank BCA, BRI, MANDIRI, BNI.

Dengan hadirnya e-money ini maka akan memberikan keakurasian informasi finansial, hal ini terkait dengan sistem informasi akuntansi yang dapat diketahui dari seberapa banyak uang yang masuk melalui pelabuhan dimana terkoneksi langsung melalui rekening/ menggunakan sistem digital non tunai. Sehingga dapat mempermudah dalam proses pembukuan. Jika tanpa adanya e-money dalam kegiatan transaksi di pelabuhan, maka tidak menutup kemungkinan akan terjadi tindakan penyelewengan salah satunya seperti penilapan uang oleh oknum yang tidak bertanggungjawab, akan tetapi dengan hadirnya e-money ini tindakan-tindakan tersebut dapat terminimalisir.

Berdasarkan pengamatan peneliti, bahwa telah ditemukan beberapa fenomena terkait dengan Kebijakan Gerakan Nasional Non Tunai di Pelabuhan Internasional Sri Bintan Pura. Diantara fenomena yang didapatkan adalah bahwa kebijakan itu belum sepenuhnya dilaksanakan oleh pengelola Pelabuhan SBP meskipun kebijakan itu sudah dilakukan atau dicanangkan sejak Juli 2018. Hal ini bisa dilihat dari beberapa indikasi, diantaranya yaitu;

Pertama, peneliti menemukan empat unit mesin berjejer menghiasi tempat antrean pass masuk, tidak lain ialah mesin e-ticketing yang hanya berfungsi beberapa bulan saja. Tidak berfungsinya mesin e-ticketing ini disebabkan memiliki masalah jaringan server yang berpusat di Kota Medan yang menyebabkan mesin ini mati. E-ticketing merupakan program dari Kementrian Perhubungan (KEMENHUB) kemudian dilaksanakan oleh Kantor Kesyahbandaran Otoritas Pelabuhan (KSOP), dari KSOP menunjuk Pelindo untuk diuji coba agar pelaksanaannya berjalan. Pelindo berharap e-ticketing ini akan berjalan $100 \%$, tetapi seiring dijalankan, ternyata KSOP tidak mendukung program ini, mereka hanya menunjuk Pelindo untuk menguji coba tetapi mereka tidak ikut mendukung program e-ticketing ini. Disamping itu kurangnya pula mempromosikan mesin ini kepada pengguna jasa, serta kekurangan Sumber Daya Manusia (SDM).

\section{Gambar Tiket Pass Masuk Bentuk Konvensional}

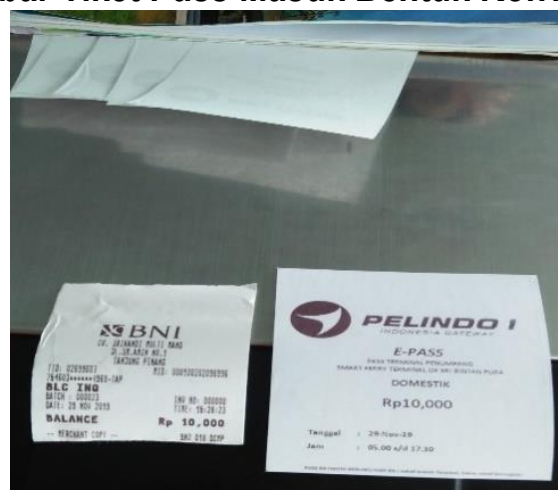

Sumber: Data Observasi Lapangan, 29 November 2019

Gambar di atas merupakan tiket konvensional, dimana tiket bertuliskan (BNI) merupakan tiket pass masuk bagi masyarakat yang melakukan perjalanan biasa. Petugas melakukan scan menggunakan kartu e-money milik mereka, setelah itu tiket tersebut dirobek lalu penumpang diperbolehkan masuk. Adapun tiket bertuliskan Pelindo 1 merupakan tiket pass masuk yang tidak dirobek sebagai bukti bagi masyarakat yang melakukan perjalanan dinas.

Kedua, e-money menuai kontra dan keluhan dari masyarakat. Kontranya, banyak masyarakat sebagai pengguna jasa di pelabuhan yang tidak setuju dengan penggunaan e-money 
karena mereka harus merogoh kocek lebih dalam dari biasanya (Kepridays.co.id, 2018). Sebagian masyarakat mengeluh tentang penerapan e-money di pelabuhan SBP, karena mereka harus membeli kartu e-money sekaligus dengan saldo tertentu meskipun hanya untuk sekali masuk (Tribunnews.com, 2018). Harga pass masuk SBP untuk pengantar dan penjemput sebesar Rp 10.000,-/ orang. Selain mengisi saldo minimal, bagi pengguna pertama juga harus membeli kartu dengan harga sekitar Rp 25.000,- sampai dengan Rp 30.000,- untuk sekali masuk.

Ketiga, saat ini e-money hanya dapat digunakan di Pelabuhan Internasional Sri Bintan Pura sebagai alat pembayaran non tunai untuk pass masuk saja, belum dapat digunakan untuk berbagai transaksi ekonomi seperti di kota-kota besar lainnya.

Keempat, masih adanya masyarakat yang belum sama sekali mengetahui tentang keberadaan e-money di Pelabuhan SBP bahkan masih menggunakan cara konvensional. Masyarakat yang masih menggunakan cara konvensional, mereka membeli karcis berupa struk pass masuk sebesar Rp 10.000,- dan masih dibantu dengan kartu e-money milik petugas untuk melalui pass masuk dan struk yang mereka dapatkan, dikembalikan lagi kepada petugas pass masuk. Hal-hal tesebut disebabkan mereka mengaku bahwa jarang bepergian ke pulau-pulau, ada yang memberikan pernyataan bahwa ribet harus top up terlebih dahulu sebelum menggunakan e-money, ada yang mengeluhkan kenapa tidak sekalian tersistem dengan ATM, juga beralasan karena harga kartu e-money cukup mahal. Ada masyarakat yang menyatakan mereka sering lupa untuk membawa e-money dikarenakan mereka berpendapat bahwa e-money di Tanjungpinang khususnya di Pelabuhan SBP ini belum multifungsional sebagai alat transaksi non tunai untuk berbagai kebutuhan layaknya di kota-kota besar di Indonesia.

Kelima, menurut informasi dari salah satu Staf Operasional Pelayanan Terminal Penumpang Pelindo, bahwa pihak Pelindo sudah melakukan promosi dengan cara sosialisasi melalui sebar brosur di Gedung Gonggong sewaktu launching, mengabarkan melalui siaran RRI, dan promosi melalui SPG. Mengaku kekurangan dan adanya keterbatasan SDM. Dan berdasarkan berita (kompas.com) yang dikutip (Pratama, 2018) bahwa Pelindo membagikan kartu gratis kepada masyarakat di Pelabuhan SBP.

Keenam, pihak Pelindo tidak memaksakan masyarakat untuk memiliki dan menggunakan e-money. Karena merasa terbebani dengan harga kartu e-money dan berpandangan bahwa mayoritas masyarakat Tanjungpinang paling banyak bertujuan ke pulau, dan memandang bahwa perspektif masyarakat pulau yang bersifat acuh tak acuh dan tidak mengetahui akan pentingnya memiliki serta menggunakan e-money.

Dari peristiwa-peristiwa yang kemudian menjadi fenomena tersebut, maka mengapa perilaku orang seperti itu. Intinya bahwa GNNT itu sudah dicanangkan di Pelabuhan Sri Bintan Pura sejak Juli 2018, tetapi ternyata sampai dengan hari ini belum berjalan sebagaimana yang diharapkan. Berangkat dari latar belakang yang telah diuraikan di atas, maka perumusan masalah dalam penelitian ini adalah bagaimanakah Implementasi Kebijakan Gerakan Nasional Non Tunai Melalui Electronic Money di Pelabuhan Internasional Sri Bintan Pura Tanjungpinang, serta tujuan penelitian ini yaitu untuk mengetahui Implementasi Kebijakan Gerakan Nasional Non Tunai Melalui Electronic Money di Pelabuhan Internasional Sri Bintan Pura Tanjungpinang.

\section{LANDASAN TEORI}

\section{Implementasi Kebijakan}

Menurut Van Meter \& Van Horn, (1975:447) beliau mengungkapkan bahwa implementasi kebijakan mencakup tindakan-tindakan yang dapat dilakukan oleh individu, pejabat atau secara berkelompok, pemerintah maupun swasta diarahkan untuk mencapai tujuan yang telah ditetapkan dalam kebijakan sebelumnya. Selanjutnya Van Meter \& Van Horn, (1975:462-472) 
menyatakan bahwa ada enam variabel yang harus diperhatikan karena dapat mempengaruhi keberhasilan implementasi. Variabel-variabel tersebut antara lain:

1) Policy standards and objectives;

2) Policy resources;

3) Interorganizational communication and enforcement activities;

4) The characteristics of the implementing agencies;

5) Economic, Social, and Political Conditions;

6) The Disposition of Implementors

\section{Uang Elektronik (Electronic Money)}

Mentari \& M.A.D.E., (2018:648) menjelaskan bahwa salah satu produk Gerakan Nasional Non Tunai adalah penggunaan uang elektronik. Uang elektronik diperkenalkan di Indonesia sejak tahun 2007. Namun pada saat itu uang elektronik masih memiliki peraturan yang sama dengan Alat Pembayaran dengan Menggunakan Kartu (APMK). Di tahun 2009, pemerintah baru memisahkan peraturan mengenai uang elektronik dari APMK yaitu Peraturan Bank Indonesia (PBI) No. 11/12/PBI/2009 tanggal 13 April 2009 mengkhusus mengenai uang elektronik. BI telah mengadopsi pendekatan yang lebih hati-hati. Sudah ada perijinan bank dan nonbank untuk uang elektronik, dan memberikan persetujuan peraturan resmi di tahun 2009.

Selanjutnya Lintangsari et al., (2018:48) memaparkan, e-money memudahkan dan mendukung kebutuhan aktivitas manusia dalam banyak hal misalnya membayar tol, transaksi umum seperti membeli pulsa dan berbelanja. Berbeda dengan kartu ATM, kartu debit, dan kartu kredit yang terhubung langsung ke rekening pengguna, transaksi melalui e-money tidak terhubung dengan rekening pengguna melainkan memiliki kantong sendiri yang dapat diisi ulang dengan cara top-up. Selain itu dalam PBI Nomor 20/6/PBI/2018 Tentang Uang Elektronik, BI memiliki wewenang menetapkan kebijakan perizinan, persetujuan, dan penyelenggaraan uang elektronik didasarkan pada pertimbangan: menjaga efisiensi nasional; mendukung kebijakan nasional; menjaga kepentingan publik; menjaga pertumbuhan industri; dan/ atau menjaga persaingan usaha yang sehat.

Widyastuti et al., (2017:39), uang elektronik dapat digolongkan menjadi dua kelompok besar, yaitu uang elektronik berbasis server (online) dan uang elektronik berbasis chip (offline). Uang elektronik berbasis chip pada umumnya digunakan untuk transaksi yang ingin dilakukan dalam waktu singkat dan frekuensinya besar, contohnya transportasi. Sementara, uang elektronik berbasis server umumnya digunakan untuk transaksi pembayaran secara online melalui web browser.

Berikut ini manfaat dan risiko penggunaan e-money menurut (Bank Indonesia, 2013). Penggunaan Uang Elektronik sebagai alat pembayaran dapat memberikan manfaat sebagai berikut:

1. Memberikan kemudahan dan kecepatan dalam melakukan transaksi pembayaran tanpa perlu membawa uang tunai.

2. Tidak lagi menerima uang kembalian dalam bentuk barang (seperti permen) akibat pedagang tidak mempunyai uang kembalian bernilai kecil (receh).

3. Sangat applicable untuk transaksi massal yang nilainya kecil namun frekuensinya tinggi, seperti: transportasi, parkir, tol, fast food, dll.

Walapun di satu sisi terdapat beberapa manfaat dari Uang Elektronik, tetapi di sisi lain terdapat risiko yang perlu disikapi dengan kehati-hatian dari para penggunanya, seperti: 
1. Risiko uang elektronik hilang dan dapat digunakan oleh pihak lain, karena pada prinsipnya uang elektronik sama seperti uang tunai yang apabila hilang tidak dapat diklaim kepada penerbit.

2. Risiko karena masih kurang pahamnya pengguna dalam menggunakan uang elektronik, seperti pengguna tidak menyadari uang elektronik yang digunakan ditempelkan 2 (dua) kali pada reader untuk suatu transaksi yang sama sehingga nilai uang elektronik berkurang lebih besar dari nilai transaksi.

Secara sederhana (Bank Indonesia, 2013) menyimpulkan bahwa, uang elektronik didefinisikan sebagai alat pembayaran dalam bentuk elektronik dimana nilai uangnya disimpan dalam media elektronik tertentu. Penggunanya harus menyetorkan uangnya terlebih dahulu kepada penerbit dan disimpan dalam media elektronik sebelum menggunakannya untuk keperluan bertransaksi. Ketika digunakan, nilai uang elektronik yang tersimpan dalam media elektronik akan berkurang sebesar nilai transaksi dan setelahnya dapat mengisi kembali (top-up). Media elektronik untuk menyimpan nilai uang elektronik dapat berupa chip atau server.

\section{Gerakan Nasional Non Tunai (GNNT)}

GNNT adalah gerakan yang dilakukan secara nasional dimana seluruh masyarakat Indonesia diajak untuk mendukung peralihan uang tunai ke non tunai. Menurut situs resmi (Bank Indonesia, 2014), Agus D.W selaku Gubernur Bank Indonesia menyatakan bahwa GNNT ditujukan untuk meningkatkan kesadaran masyarakat terhadap penggunaan instrumen non tunai, sehingga berangsur-angsur terbentuk suatu komunitas atau masyarakat yang lebih menggunakan instrumen non tunai (LCS) khususnya dalam melakukan transaksi atas kegiatan ekonominya. Implementasi GNNT tidak hanya memerlukan keterlibatan BI selaku regulator sistem pembayaran, namun juga dukungan dari Kementerian/Lembaga, Pemerintah Daerah, pelaku industri sistem pembayaran dan masyarakat. Potensi pembayaran non tunai atau yang disebut elektronifikasi pada transaksi pemerintah daerah mencakup transaksi antar pemerintah, bisnis dan mayarakat. Gerakan ini ditandai dengan penandatanganan Nota Kesepahaman antara Bank Indonesia dengan Kementerian Koordinator Bidang Perekonomian, Kementerian Keuangan, Pemerintah Daerah serta Asosiasi Pemerintahan Provinsi Seluruh Indonesia sebagai komitmen untuk mendukung GNNT.

\section{Definisi Konsep}

Definisi konsep digunakan untuk menjelaskan bagaimana teori yang penulis gunakan saat diturunkan kedalam rencana penelitian ini. Penulis menggunakan beberapa indikator dari (Van Meter \& Van Horn, 1975) sebagai berikut:

1) Standar dan tujuan kebijakan gnnt melalui e-money. Adapun standar dalam kebijakan gnnt yaitu adanya penetapan batas maksimal nilai uang elektronik; penyetaraan penggunaan nilai uang tunai dengan nilai uang elektronik; dan penggunaan uang elektronik dalam negeri menggunakan satuan uang rupiah. Kemudian, tujuan kebijakan gerakan nasional non tunai ini adalah untuk menumbuhkan/ meningkatkan kesadaran masyarakat terhadap penggunaan instrumen non tunai, sehingga berangsur-angsur terbentuk masyarakat yang lebih menggunakan instrumen non tunai (LCS) khususnya dalam melakukan transaksi atas kegiatan ekonominya.

2) Sumber daya yang dibutuhkan dalam implementasi kebijakan gnnt melalui e-money di pelabuhan SBP berupa sumber daya manusia meliputi para petugas Pelindo, dan sumber daya mesin berupa alat-alat dalam bentuk kartu beserta mesin-mesin uang elektronik. 
Sumber daya tersebut menjadi perhitungan yang sangat penting demi menunjang keberhasilan implementasi kebijakan gnnt melalui e-money di pelabuhan SBP.

3) Komunikasi antar oganisasi terkait dan kegiatan-kegiatan pelaksanaan implementasi kebijakan gnnt melalui e-money, yaitu $\mathrm{BI}$ mengontrol kegiatan pelaksanaan kebijakan tersebut di pelabuhan SBP sesuai dengan prosedur yang telah tertuang dalam PBI Nomor 20/6/PBI/2018 Tentang Uang Elektronik. Kemudian, implementasi kebijakan ini memerlukan dukungan dan koordinasi dari BI, PT. Pelindo, BUMD Kota Tanjungpinang, DPRD Komisi II Kota Tanjungpinang, Bank BNI, BRI, BCA, dan Mandiri beserta pengguna jasa di pelabuhan SBP.

4) Karakteristik organisasi pelaksana kebijakan gnnt melalui e-money di pelabuhan SBP. Dimana untuk melaksanakan kebijakan tersebut PT. Pelindo menyediakan tempat untuk mesin-mesin uang elektronik, dimana mesin-mesin dan kartu uang elektronik disediakan oleh pihak-pihak Bank yang terkait.

5) Lingkungan ekonomi, sosial, dan politik yang mempengaruhi keberhasilan implementasi kebijakan gnnt melalui e-money. Dimana lingkungan ekonomi berkaitan dengan tingkat perekonomian masyarakat. Lingkungan sosial yakni berkaitan dengan kemampuan masyarakat dalam mengadaptasi teknologi, dan lingkungan politik yaitu kebijakan pemerintah daerah.

6) Tanggapan/ sikap para pelaksana implementasi kebijakan gnnt melalui e-money di pelabuhan internasional SBP. Dimana pelaksana dapat berupa pembuat dan penerima kebijakan gnnt tersebut.

\section{METODOLOGI PENELITIAN}

\section{Jenis dan Sumber Data Penelitian}

Peneliti menggunakan jenis penelitian deskriptif dengan pendekatan kualitatif. Objek penelitian ini yaitu melihat bagaimana implementasi kebijakan Gerakan Nasional Non Tunai melalui Electronic Money di Pelabuhan Internasional Sri Bintan Pura Tanjungpinang. Lokasi penelitian dilaksanakan di Pelabuhan Internasional Sri Bintan Pura Kota Tanjungpinang.

\section{Sumber Data}

Sumber data menurut Ulber, (2012:289-291) dibedakan atas sumber data primer dan sumber data sekunder, keduanya akan memudahkan peneliti melakukan pengumpulan data.

a) Data primer, first-hand information yaitu data penelitian yang diperoleh secara langsung dari narasumber melalui interview, dimana dalam penelitian ini data primer diperoleh dari PT. Pelindo maupun instansi-instansi dan pihak-pihak lain yang terkait dengan penelitian ini. Data yang diperoleh yaitu berupa data mengenai implementasi kebijakan Gerakan Nasional Non Tunai melalui e-money di pelabuhan internasional Sri Bintan Pura Tanjungpinang.

b) Data sekunder, yaitu data yang dikumpulkan dari tangan kedua (data yang diperoleh secara tidak langsung dari sumber aslinya). Sumber data sekunder berupa buku-buku, dokumen, arsip-arsip, serta data pendukung dari sumber-sumber lain yang terkait dengan implementasi kebijakan gnnt melalui e-money di Pelabuhan Internasional SBP Tanjungpinang.

\section{Teknik Pengumpulan Data}

a) Observasi. Cartwright dan Cartwright dalam Herdiansyah, (2010:131) mendefinisikan observasi sebagai suatu proses melihat, mengamati, dan mencermati serta merekam perilaku secara sistematis untuk suatu tujuan tertentu. Observasi yang peneliti lakukan ialah observasi passive participation yang dalam hal ini peneliti datang di tempat kegiatan orang yang diamati 
tetapi tidak ikut terlibat dalam kegiatan tersebut. Alat yang penulis gunakan berupa daftar catatan (check list).

b) Wawancara. Menurut Esterberg Sugiyono, (2011:231), wawancara merupakan pertemuan dua orang untuk bertukar informasis dan ide melalui tanya jawab, sehingga dapat dikonstruksikan makna dalam suatu topik tertentu. Dalam penelitian kualitatif, wawancara menjadi metode pengumpulan data utama, sebagian besar data diperoleh melalui wawancara. Alat yang penulis gunakan berupa pedoman wawancara.

c) Dokumentasi. Sugiyono, (2018:240) mendefinisikan, dokumen merupakan catatan peristiwa yang sudah berlalu. Dokumen bisa berbentuk tulisan, gambar, atau karya-karya monumental dari seseorang. Alat yang penulis gunakan berupa dokumen dan kamera.

\section{Informan}

Menurut Moleong, (2007:90) informan adalah orang yang dimanfaatkan untuk memberikan informasi tentang situasi dan kondisi latar belakang penelitian. Pemilihan informan yang akan diwawancarai sebagai sumber data dalam penelitian ini menggunakan teknik purposive sampling. Untuk mendapatkan informasi penulis akan mewawancarai beberapa informan yang berkaitan dengan judul penelitian, yakni sebagai berikut:

Tabel Data Informan

\begin{tabular}{|c|c|c|c|}
\hline No. & Informan Penelitian & Pertimbangan & Jumlah \\
\hline 1 & $\begin{array}{l}\text { Pimpinan Pelabuhan/ } \\
\text { General Manager }(\mathrm{GM}) \\
\text { Pelindo. }\end{array}$ & $\begin{array}{l}\text { Menyelenggarakan dan melaksanakan } \\
\text { pengusahaan dan pelayanan jasa } \\
\text { kepelabuhanan. }\end{array}$ & 1 orang \\
\hline 2 & $\begin{array}{l}\text { Staff Operasional } \\
\text { Pelayanan Terminal } \\
\text { Penumpang Pelindo }\end{array}$ & $\begin{array}{l}\text { Memiliki tugas pokok melaksanakan, } \\
\text { mengawasi dan mengevaluasi kegiatan } \\
\text { pelayanan terminal penumpang, dan } \\
\text { pelayanan pas pelabuhan. }\end{array}$ & 2 orang \\
\hline 3 & $\begin{array}{l}\text { Petugas E-Pass } \\
\text { Internasional dan } \\
\text { Domestik. }\end{array}$ & $\begin{array}{l}\text { Melayani pass pelabuhan tujuan internasional } \\
\text { dan domestik. }\end{array}$ & 2 orang \\
\hline 4 & $\begin{array}{l}\text { Badan Usaha Milik } \\
\text { Daerah (BUMD) Kota } \\
\text { Tanjungpinang. }\end{array}$ & $\begin{array}{l}\text { Lebih kepada teknisnya sebagai penerima } \\
\text { Dana Bagi Hasil (DBH) }\end{array}$ & 1 orang \\
\hline 5 & $\begin{array}{l}\text { Dewan Perwakilan Rakyat } \\
\text { Daerah (DPRD) Komisi II } \\
\text { Kota Tanjungpinang. }\end{array}$ & $\begin{array}{l}\text { Lembaga yang memiliki kewenangan dalam } \\
\text { hal pengawasan terhadap eksekutif. }\end{array}$ & 1 orang \\
\hline 6 & $\begin{array}{l}\text { Pimpinan Bank BNI, BRI, } \\
\text { BCA, dan Mandiri. }\end{array}$ & Bank sebagai penerbit kartu $e$-money. & $\begin{array}{l}\text { Masing- } \\
\text { masing } \\
1 \text { orang }\end{array}$ \\
\hline 7 & $\begin{array}{l}\text { Pengguna Jasa di } \\
\text { Pelabuhan. }\end{array}$ & Pengguna Jasa di Pelabuhan. & 4 orang \\
\hline
\end{tabular}

Sumber data: Olahan Peneliti, 2020. 
Menurut Sugiyono, (2011:218-219), purposive sampling adalah teknik pengambilan sampel sumber data dengan pertimbangan tertentu, misalnya orang tersebut yang dianggap paling tahu tentang apa yang kita harapkan, atau mungkin dia sebagai penguasa sehingga akan memudahkan peneliti menjelajahi obyek/ situasi sosial yang diteliti.

\section{Teknik Analisa Data}

Sugiyono, (2018:244) analisis data adalah proses mencari dan menyusun secara sistematis data yang diperoleh dari hasil wawancara, catatan lapangan, dan dokumentasi, dengan cara mengorganisasikan data ke dalam kategori, menjabarkan ke dalam unit-unit, melakukan sintesa, menyusun ke dalam pola, memilih mana yang penting dan yang akan dipelajari, dan membuat kesimpulan sehingga mudah dipahami oleh diri sendiri maupun orang lain. Adapun menurut Miles dan Huberman dalam Ulber, (2012:339-341) kegiatan analisis data terdiri dari:

a) Reduksi Data, merupakan suatu bentuk analisis yang menajamkan, menggolongkan, mengarahkan, membuang yang tidak perlu, dan mengorganisasikan data sedemikian rupa hingga kesimpulan-kesimpulan finalnya dapat ditarik dan diverifikasi.

b) Penyajian Data, yaitu sebagai sekumpulan informasi tersusun yang memberi kemungkinan adanya penarikan kesimpulan dan pengambilan tindakan. Melalui data yang disajikan, kita melihat dan akan dapat memahami apa yang sedang terjadi dan apa yang harus dilakukan lebih jauh menganalisis ataukah mengambil tindakan berdasarkan atas pemahaman yang didapat dari penyajian-penyajian tersebut.

c) Menarik Kesimpulan dan Verifikasi, dilakukan sejak awal terhadap data yang diperoleh, tetapi kesimpulannya masih kabur (bersifat tentatif), diragukan tetapi semakin bertambahnya data maka kesimpulan itu lebih "grounded" (berbasis data lapangan). Kesimpulan harus diverifikasi selama penelitian berlangsung. Singkatnya makna-makna yang muncul dari data harus diuji kebenarannya, kekukuhannya dan kecocokannya, yakni merupakan validitasnya. Jika tidak demikian, maka sesuatu itu tidak jelas kebenarannya.

\section{HASIL DAN PEMBAHASAN}

\section{Hasil Penelitian}

Penelitian yang dilakukan yaitu tentang Implementasi Kebijakan GNNT Melalui E-Money di Pelabuhan Internasional SBP Tanjungpinang. Pemerintah melalui Gubernur Bank Indonesia mengeluarkan kebijakan GNNT melalui Peraturan Bank Indonesia (PBI) Nomor 20/6/PBI/2009 tentang Uang Elektronik. Kebijakan GNNT melalui e-money mulai diimplementasikan di Tanjungpinang, khususnya di Pelabuhan Internasional SBP.

Kebijakan ini mengajak masyarakat untuk mendukung peralihan penggunaan alat pembayaran dari tunai ke nontunai. Hal ini memiliki arti bahwa masyarakat tidak terlalu bergantung dengan uang tunai setiap kali bertransaksi. Tujuannya adalah untuk meningkatkan kesadaran masyarakat terhadap penggunaan instrumen nontunai, sehingga dapat terbentuk LCS dalam melakukan transaksi atas kegiatan ekonominya.

Pelabuhan ini merupakan salah satu pelabuhan dengan lalu lintas penumpang terbanyak, dimana menjadi akses pintu gerbang utama bagi keluar dan masuknya wisatawan domestik maupun mancanegara, disamping itu pelabuhan ini merupakan salah satu jalur laut yang sering digunakan masyarakat untuk memenuhi kebutuhannya. Maka dengan letaknya yang strategis berada di kepulauan, Kementerian Perhubungan menjadikan Pelabuhan Internasional Sri Bintan Pura sebagai pilot project, yaitu pelabuhan pertama di Indonesia yang menggunakan 
uang elektronik untuk menyukseskan GNNT, dilaksanakan pada tahun 2018 dengan menunjuk Pelindo 1 sebagai pelaksananya.

Implementasi Kebijakan GNNT melalui e-money di Pelabuhan Internasional SBP Tanjungpinang, tidak akan berjalan tanpa adanya keterlibatan antar implementor, stakeholders dan masyarakat/ pengguna jasa pelabuhan. Oleh karena itu implementasi ini dijalankan oleh PT. Pelindo 1 Cabang Tanjungpinang sebagai pelaksana implementasi kebijakannya, Keempat Bank (BRI, BNI, Mandiri, dan BCA) sebagai Vendors-nya, dan Badan Usaha Milik Daerah PT. Tanjungpinang Makmur Bersama (BUMD PT. TMB) Tanjungpinang sebagai pengelola Dana Bagi Hasil (DBH) yang didapatkan dari kebijakan GNNT melalui e-money di SBP, DPRD Komisi II Kota Tanjungpinang sebagai pengawas terhadap aturan berjalannya implementasi ini, serta masyarakat sebagai pengguna jasa pelabuhan yang menjadi sasaran dalam penggunaan Uang Elektronik.

\section{Gambar Grafik Trafik Kunjungan Kapal Penumpang Terminal Sri Bintan Pura Januari-} Desember 2020

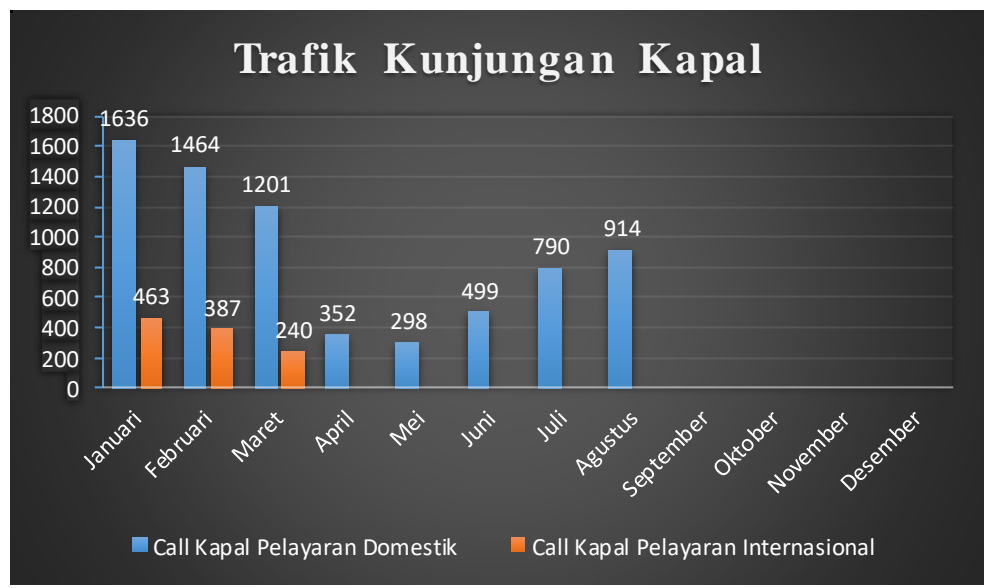

Sumber: PT. Pelindo1 Cabang Tanjungpinang, 2020.

Namun saat pandemi Corona Virus Deases (Covid 19) muncul dan diberlakukannya lockdown pada negara tetangga membuat jumlah pelayaran bagian internasional semakin menurun hingga bulan Maret, bahkan tidak ada jumlah pelayaran sama sekali mulai dari bulan April. Begitupun untuk pelayaran domestik ke pulau-pulau seperti Lingga, Anambas, dan lain-lain sempat diberlakukan lockdown selama beberapa minggu membuat jumlah pelayaran semakin menurun, kecuali pelayaran ke Batam masih tetap berjalan. Kemudian sistem metode pembayaran pengelolaan dana hasil e-berthting dalam hal ini merupakan urusan pihak Pelindo 1 dengan kantor pusat yang bertempat di Medan.

Seperti yang telah penulis paparkan pada bagian latar belakang, bahwa tidak berfungsinya mesin e-ticketing disebabkan memiliki masalah jaringan server yang berpusat di Kota Medan yang menyebabkan matinya mesin ini. Namun setelah melakukan wawancara yang lebih intensif, peneliti menemukan bahwa tidak berfungsinya mesin e-ticketing bukan disebabkan masalah jaringan server yang berpusat di Kota Medan, melainkan disebabkan tidak bertemunya kesepakatan pada sistem metode pembayaran antara kedua belah pihak yakni pihak agen pelayaran dengan PT. Pelindo 1. Selain itu, mobile aplikasi Nyebrang Yuk! Juga tidak berfungsi dengan baik. Dapat dilihat pada menu event, ketika dipilih opsi menu event muncul pemberitahuan seperti gambar di bawah ini: 


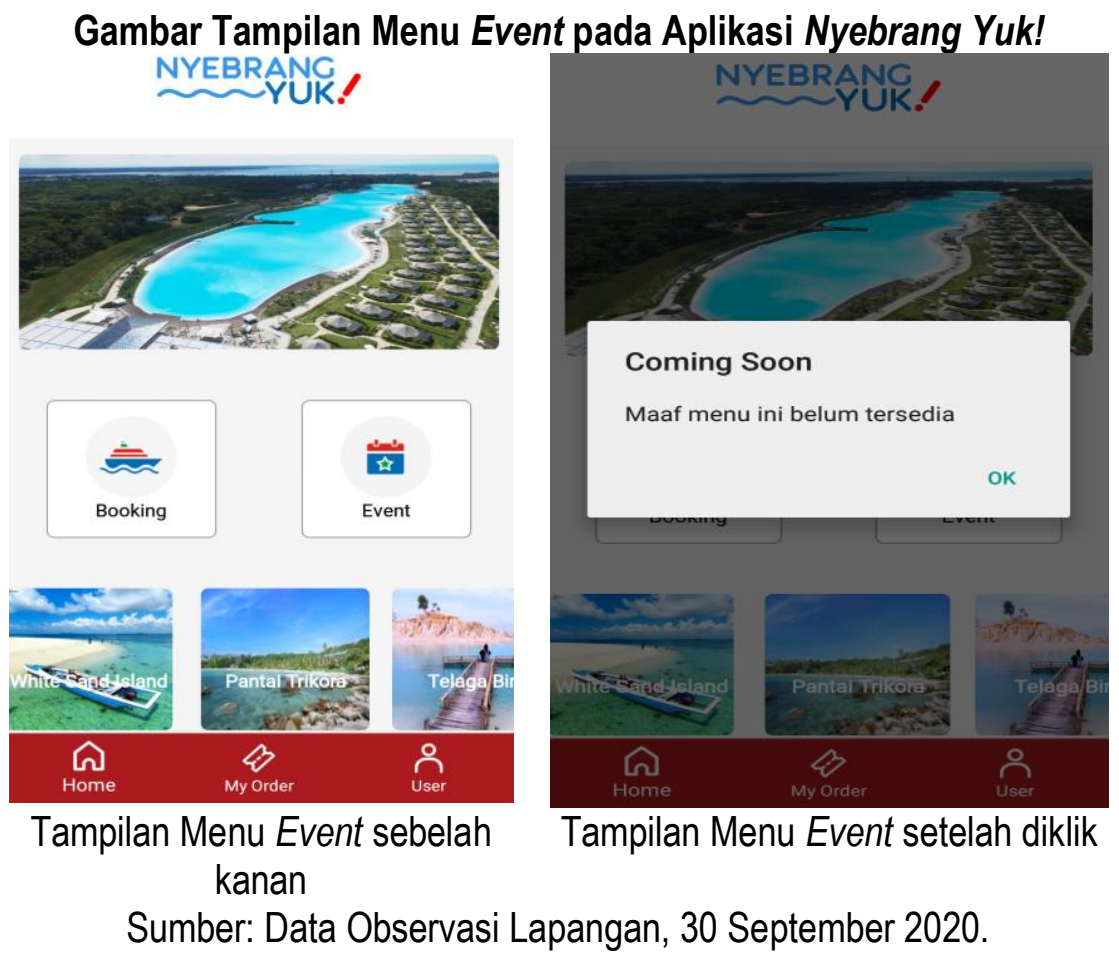

Selain hal tersebut, mobile app Nyebrang Yuk! Tidak bisa digunakan untuk memesan tiket, jika hendak memesan tiket kemudian setelah pilih opsi menu booking, muncullah halaman "Pilih Keberangkatan" sekaligus muncul pemberitahuan "Tidak ada keberangkatan yang ditampilkan!", ketika kita baru mengetik satu huruf, setelah itu akan keluar dengan sendirinya dan langsung kembali ke tampilan halaman utama seperti gambar di bawah ini:

\section{Gambar Tampilan Menu Booking pada Aplikasi Nyebrang Yuk!} NYEBRANG!

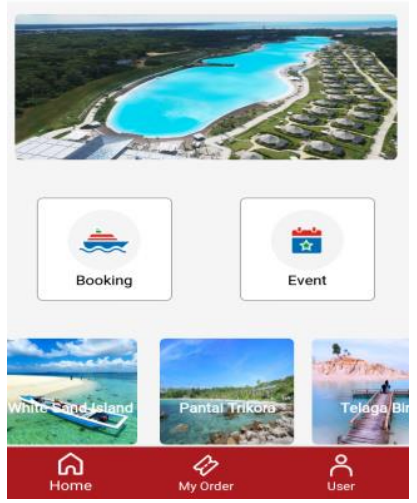

Tampilan Menu Booking Sebelah Kiri dari Menu Event
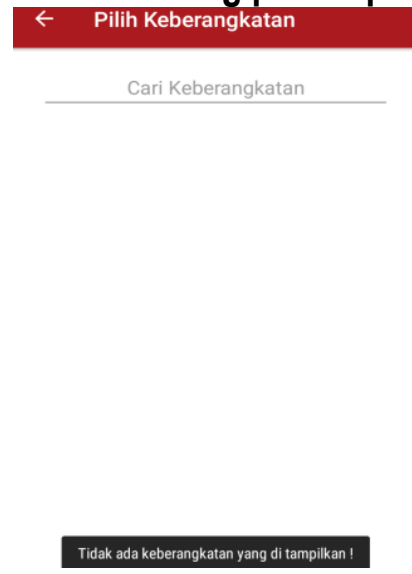

Tampilan Setelah Mengklik Menu Booking

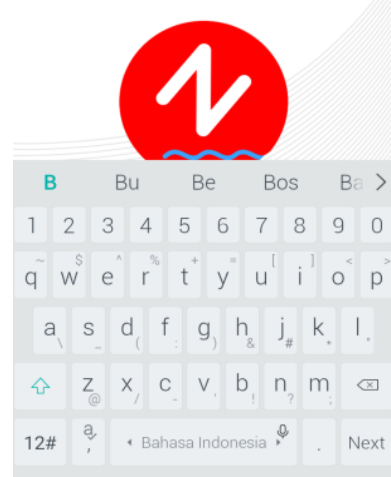

Tampilan Kembali ke Halaman Utama

Sumber: Data Observasi Lapangan, 30 September 2020.

Namun kegiatan Tiket Masuk Elektronik (e-pass) tetap berjalan meskipun masih ada yang menggunakan uang tunai. Hal ini disebabkan oleh kontra masyarakat yang tidak mau menggunakan kartu e-pass dengan berbagai alasan. Bahkan ada masyarakat yang melakukan pengaduan/ protes kepada DPRD mengenai penggunaan kartu uang elektronik di Pelabuhan SBP. Protes tersebut berisi keluhan masyarakat yang mengeluh karena hanya sekali berangkat 
dalam setahun. Kemudian DPRD menindaklanjuti keluhan tersebut dengan bertemu pihak Pelindo untuk menyarankan supaya GM Pelindo menyediakan pembelian pass manual.

Peristiwa tersebut membuat GM Pelindo 1 mengambil jalan tengah, yaitu dengan tetap menggunakan kartu e-pass dan menggunakan cara konvensional/ manual yaitu dengan membeli tiket pass konvensional menggunakan uang tunai. Bagi pengguna pass konvensional, Pelindo1 sudah menerbitkan tiket pass masuk yang baru setelah sebelumnya menggunakan dua jenis tiket pass masuk, kini hanya menggunakan satu model tiket saja. Fungsinya sebagai pass masuk perjalanan biasa sekaligus digunakan sebagai bukti perjalanan dinas bagi masyarakat yang melakukan perjalanan dinas.

Demi memenuhi tanggungjawab sebagai pelaksana/ implementor, pihak Pelindo 1 telah memberikan opsi dengan menerapkan dua sistem yaitu sistem tunai dan non tunai. Pada sistem tunai saat akan memasuki pintu gate, pengguna jasa memberikan tiket pass kepada petugas, sedangkan untuk sistem non tunai pengguna jasa langsung men-tapping kartu e-pass.

\section{Gambar Melewati Gate Pass Domestik Menggunakan Tiket Konvensional}

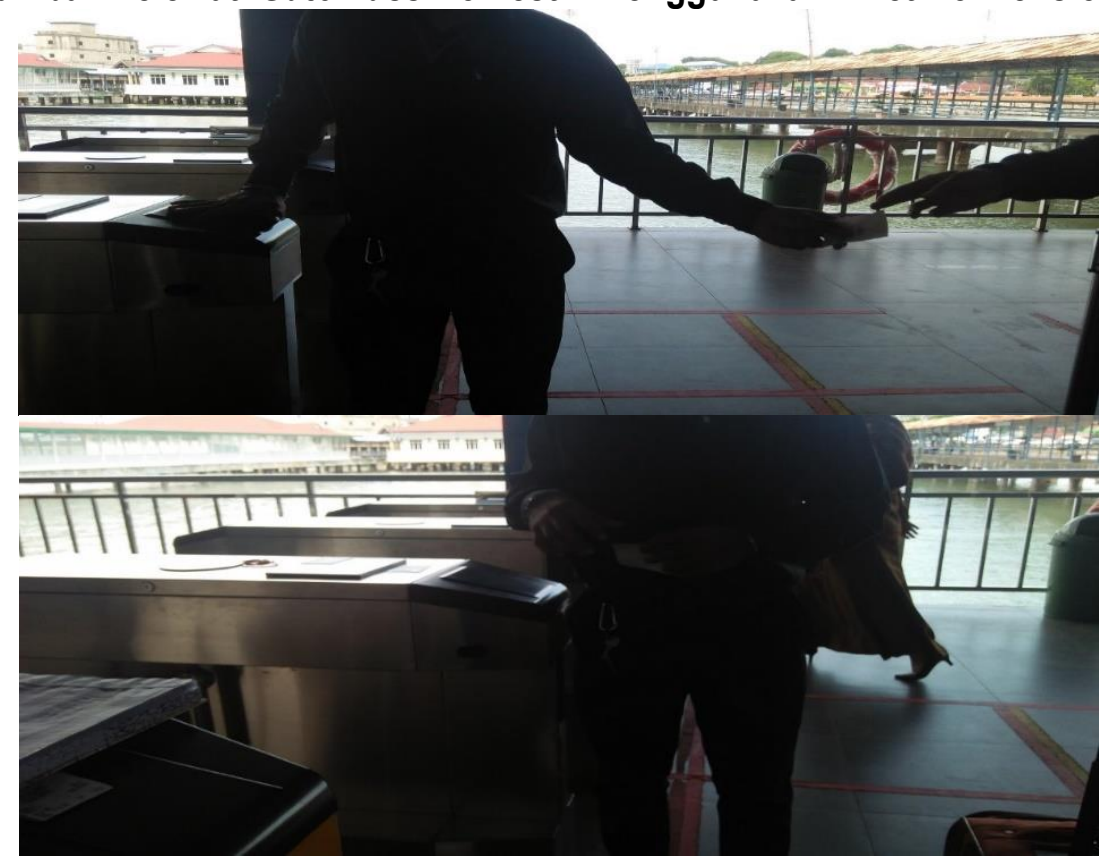

Sumber: Data Observasi Lapangan, 27 Juli 2020.

Kedua gambar di atas menunjukkan pengguna jasa yang menggunakan tiket masuk konvensional yakni dengan cara menyerahkan tiket tersebut kepada petugas, kemudian petugas tersebut men-tapping kartu uang elektronik miliknya lalu gate terbuka, pengguna jasa dapat melewati gate. Setelah itu agar tidak terjadi kecurangan tiket, petugas merusak tiket konvensional yang sudah terpakai. Namun hal ini membuat tidak dapat dibedakannya mana yang menggunakan kartu elektronik dan mana yang memakai tiket konvensional. Hal ini dapat diamati dengan data jumlah penumpang yang memasuki pintu gate baik pada gate domsetik maupun gate internasional. 


\section{Gambar Jumlah Penumpang yang Melewati Pintu Pass (Gate) Menggunakan Kartu Uang Elektronik.}

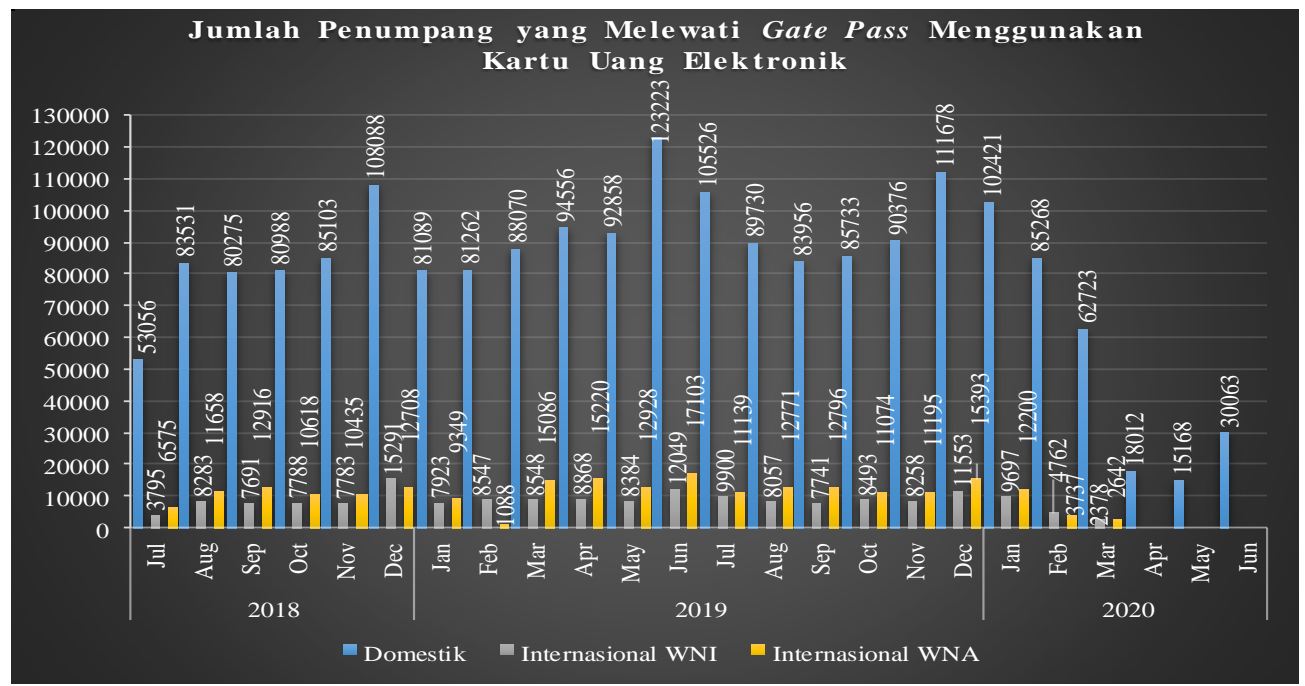

Sumber: PT. Pelindo 1 Cabang Tanjungpinang, 2020.

Pada grafik di atas, dapat diamati bahwa jumlah penumpang yang melewati gate pass menggunakan kartu uang elektronik digabungkan dari semua kartu yang di keluarkan oleh pihak bank, diantaranya kartu e-pass BRIZZI, Tap Cash, Flazz, maupun Mandiri e-money. Begitupun dengan pengguna tiket konvensional yang melewati gate dengan kartu milik petugas. Hal tersebut disebabkan tidak adanya sistem yang memisahkan mana pengguna keempat kartu epass tersebut, dan mana pengguna jasa pelabuhan yang menggunakan pass konvensional, pada akhirnya jumlah pengguna jasa digabung semuanya. Kemudian di minggu terakhir bulan Juli 2020 barulah diadakan pencatatan pemisah antara pengguna kartu e-pass dengan yang konvensional.

Memasuki tahun 2020, dengan hadirnya pandemic Covid 19 ke Tanjungpinang dan berbagai daerah, implementasi ini tetap dijalankan dengan menggunakan protokol kesehatan sesuai anjuran pemerintah. Gate internasional ditutup sementara sampai batas waktu yang belum ditentukan dikarenakan masih diberlakukannya lockdown di Negara tetangga seperti Singapur dan Malaysia. Oleh karena itu SOP di pelabuhan SBP ditambahkan sesuai protokol demi keamanan dan kesehatan pengguna jasa maupun seluruh petugas pelindo agar terhindar dari virus Covid 19. Maka dari itu untuk membahas implementasi kebijakan ini lebih lanjut, peneliti menggunakan enam indikator dari Van Meter dan Van Horn. Sebelum itu peneliti menguraikan identitas responden terlebih dahulu.

Adapun analisis dari 6 indikator Van Meter dan Van Horn sebagai berikut:

\section{Analisis Standar dan Tujuan Kebijakan GNNT Melalui E-Money di Pelabuhan Sri Bintan Pura}

- Penetapan batas maksimal nilai uang elektronik, penyetaraan penggunaan nilai uang tunai dengan nilai uang elektronik, dan penggunaan uang elektronik dalam negeri menggunakan satuan uang rupiah sudah sesuai pelaksanaannya di lapangan.

- Tolak ukur keberhasilan dari masing-masing bank belum sepenuhnya tercapai.

- Syarat dan ketentuan penggunaan e-money berlaku sama dan sudah sesuai dengan implementasi di lapangan.

-SOP E-pass tidak sesuai dengan implementasi di lapangan karena menerapkan dua metode (konvensional dan modern) 
- SOP E-Ticketing tidak berlaku karena kegiatan e-ticketing tidak berjalan.

- Kegiatan E-Berthing berjalan sesuai dengan SOP

Analisis Sumber daya yang dibutuhkan dalam implementasi kebijakan gnnt melalui emoney di pelabuhan SBP

- Sumber daya manusia sudah mencukupi

- Sumber daya mesin memiliki kendala (produk kartu e-pass tidak tersedia di loket, jumlah mesin $E D C$ berkurang, dan mesin e-ticketing tidak dioperasikan lagi)

- Sumber daya finansial. Anggaran tidak spesifik dan menjadi sebuah rahasia/ tidak bisa dijadikan sebagai konsumsi publik, hasil dana e-ticketing dan e-berthing dikelola pihak Pelindo1 dengan kantor pusat di Medan, hasil dana e-pass dikelola oleh pihak BUMD PT.TMB dengan Pelindo.

- Sumber daya waktu. Tidak ada target waktu ntuk keberhasilan kebijakan ini, masih ada keterlambatan penyerahan $\mathrm{DBH}$.

Analisis Komunikasi antar oganisasi terkait dan kegiatan-kegiatan pelaksanaan implementasi kebijakan gnnt melalui e-money

- Para pihak pelaksana melakukan rapat. Kemudian edukasi dan sosialisasi kepada massyarakat. Dalam koordinasi pihak pelaksana melakukan pengawasan secara langsung dan tidak langsung demi berjalannya kebijakan ini, namun pihak Pelindo1 dengan agen pelayaran belum menemukan solusi atas sistem pembayaran hasil e-ticketing. Hal itu menunjukkan bahwa badan-badan pelaksana (implementor) tersebut belum memiliki suatu pemahaman informasi yang sama agar komunikasi ini berjalan dengan efektif. Implementasi kebijakan GNNT ini kurang mendapat dukungan dan koordinasi dari pihak agen pelayaran. Oleh sebab itu, terbukti bahwa komunikasi antar organisasi terkait ini merusak jalannya implementasi kebijakan yang dijalankan, sehingga komunikasi dan koordinasi yang dilakukan belum dapat tercapai dengan baik serta menghambat dalam mencapai tujuannya untuk menumbuhkan/ meningkatkan kesadaran masyarakat terhadap penggunaan instrumen non tunai yang bersangsur untuk membentuk LCS dalam melakukan transaksi atas kegiatan ekonominya.

Analisis Karakteristik organisasi pelaksana kebijakan gnnt melalui e-money di pelabuhan SBP.

- Masing-masing pihak pelaksana sudah memiliki perannya dalam mendukung kebijakan ini meskipun tidak terpaut dalam suatu organisasi khusus. Namun masih ada kendala pada pihak Pelindo pusat yang mana sering terlambat dalam penyerahan DBH kepada BUMD PT. TMB.

Analisis Lingkungan ekonomi, sosial, dan politik yang mempengaruhi keberhasilan implementasi kebijakan gnnt melalui e-money.

- Lingkungan ekonomi masyarakat sekitar belum seluruhnya mampu menggunakan e-money meskipun harga yang di tetapkan sudah sesuai, lingkungan sosial masyarakat yang terbiasa menggunakan tunai sangat berpengaruh dalam kebijakan ini, lingkungan politik sudah mendukung dengan adanya kerjasama pemerintah.

Analisis Tanggapan/ sikap para pelaksana implementasi kebijakan gnnt melalui e-money di pelabuhan internasional SBP.

- Semua agen pelaksana menerima dan mendukung kebijakan ini, namun masih banyak kekurangan yang perlu diperbaiki dan pentingnya respon pelaksana dari saran yang masuk demi suksesnya kebijakan ini. Semua agen pelaksana berharap kebijakan ini bisa berjalan dengan maksimal kedepannya. 


\section{Rekomendasi}

Rekomendasi yakni perlu ditinjau lagi sosialisasinya agar lebih maksimal, diberikannya reward kepada pengguna jasa pelabuhan agar lebih memahami dan tertarik menggunakan emoney, kemudian diberlakukannya aturan syarat masuk pelabuhan harus menggunakan emoney sehingga tidak ada penggunaan tunai dalam bertransaksi menggunakan jasa di Pelabuhan Internasional SBP Tanjungpinang.

1. Untuk indikator standar dan tujuan kebijakan, peneliti menyarankan sebaiknya sosialisasi dilakukan lagi secara mendetail ke seluruh lapisan masyarakat terutama sosialisasi intens ke pelosok desa, sekolah dan universitas agar pemahaman masyarakat lebih luas sehingga transaksi ekonomi sudah berpindah menggunakan e-money. Selain itu, pihak implementor harus tegas dan konsisten terhadap praktek penggunaan uang elektronik di lapangan dengan hanya satu metode yaitu masyarakat harus menggunakan e-money dalam bertransaksi di Pelabuhan SBP.

2. Untuk sumber daya, peneliti memiliki saran yaitu perlu di upgrade lagi sistem pada uang elektronik berbentuk chip (kartu e-pass) agar diberi sistem keamanan. Selain hal itu, sistem aplikasinya harus terus di perbaiki dan harus terus di upgrade agar masyarakat bisa menggunakannya meskipun di rumah jika ingin memesan tiket.

3. Untuk indikator komunikasi antar organisasi terkait dan kegiatan-kegiatan pelaksanaan, peneliti memiliki saran yakni terus berupaya mencari jalan tengah agar mendapatkan kesepakatan metode pembayaran antara Pelindo1 dengan pihak agen pelayaran supaya mesin e-ticketing dioperasikan kembali.

4. Selanjutnya untuk indikator karakteristik organisasi pelaksana, peneliti menyarankan koordinasi antar organisasi sebaiknya lebih ditekankan lagi dan tanggung jawab atas peran yang di laksanakan agar tidak ada kesalah pahaman antara pihak pelaksana.

5. Untuk indikator lingkungan ekonomi, sosial dan politik, peneliti menyarankan secepatnya implementasi penggunaan e-money di terapkan di berbagai tempat agar penggunaan emoney bisa bertransaksi dimana saja.

6. Untuk indikator tanggapan/ sikap para pelaksana, peneliti menyarankan perlu dilakukannya survey tingkat kepuasan dan saran masyarakat terhadap penggunaan transaksi non tunai di Pelabuhan Internasional SBP.

\section{DAFTAR PUSTAKA}

\section{Buku dan Jurnal}

Herdiansyah, H. (2010). Metodologi Penelitian Kualitatif untuk IImu-ilmu Sosial (R. Oktafiani (ed.)). Penerbit Salemba Humanika.

Jacobs, P. (2014). Gerai Info Edisi 50. Mengurangi Ketergantungan Pada Uang Tunai. Bank Indonesia, 1-24. https://www.bi.go.id/id/publikasi/gerai-info/Pages/Gerailnfo-Edisi5014.aspx

Lintangsari, N. N., Hidayati, N., Purnamasari, Y., Carolina, H., \& Ramadhan, W. F. (2018). Analisis Pengaruh Instrumen Pembayaran Non-Tunai Terhadap Stabilitas Sistem Keuangan di Indonesia. Jurnal Dinamika Ekonomi Pembangunan, 1(1), 47-62. https://doi.org/10.14710/jdep.1.1.47-62

Mentari, A. C., \& M.A.D.E., I. K. G. B. (2018). Analisis Faktor-Faktor yang Mempengaruhi Minat dalam Menggunakan Uang Elektronik di Kota Denpasar, Provinsi Bali. E-Jurnal Ekonomi Pembangunan Universitas Udayana, 7(4), 646-676.

Moleong, L. J. (2007). Metodologi Penelitian Kualitatif. PT. Remaja Rosdakarya. 
Sugiyono. (2011). Metode Penelitian Kuantitatif, Kualitatif, dan R\&D (13th ed.). Alfabeta.

--. (2018). Metode Penelitian Kuantitatif, Kualitatif, dan R\&D. Alfabeta.

Ulber, S. (2012). Metode Penelitian Sosial. Refika Aditama.

Van Meter, D. S., \& Van Horn, C. E. (1975). The Policy Implementation Process A Conceptual Framework. Administration \& Society, 6(4), 445-488.

Widyastuti, K., Handayani, P. W., \& Wilarso, I. (2017). Tantangan dan Hambatan Implementasi Produk Uang Elektronik di Indonesia: Studi Kasus PT XYZ. Jurnal Sistem Informasi (Journal of Information Systems), 38-48.

\section{Website:} https://doi.org/http://dx.doi.org/10.21609/jsi.v13i1.465

Bank Indonesia. (2013). Edukasi dan Perlindungan Konsumen. https://www.bi.go.id/id/edukasiperlindungan-konsumen/edukasi/produk-dan-jasa-sp/uang-elektronik/Pages/default.aspx

Bank Indonesia. (2014). Media Room. www.bi.go.id/en/ruang-media/info-terbaru/Pages/BIdukung-penyaluran-program-bantuan-pemerintah-non-tunai.aspx

Kepridays.co.id. (2018). E-Money Pass Pelabuhan Tuai Pro-Kontra. https://kepridays.co.id/2018/07/26/e-money-pass-pelabuhan-tuai-pro-kontra/

Nikolas, P. (2018, July 4). Pelabuhan Tanjungpinang Jadi Percontohan E-Money Nasional. Antaranews. https://www.antaranews.com/berita/724105/pelabuhan-tanjungpinang-jadipercontohan-e-money-nasional

Pratama, A. M. (2018). Pelindo I Bagikan Kartu E-Money di Pelabuhan Tanjungpinang. Kompas.com. amp.kompas.com/ekonomi/read/2018/07/05/024556826/pelindo-i-bagikankartu-e-money-di-pelabuhan-tanjung-pinang

Tribunnews.com. (2018). E-Pass Pelabuhan Sri Bintan Pura Dikeluhkan, DPRD Panggil Pelindo Tanjungpinang. https://batam.tribunnews.com/2018/07/26/e-pass-pelabuhan-sri-bintanpura-dikeluhkan-dprd-panggil-pelindo-tanjungpinang

\section{Dokumen:}

Peraturan Bank Indonesia Nomor 20/6/PBI/2018 Tentang Uang Elektronik, (2018).

Undang-Undang Republik Indonesia Nomor 17 Tahun 2008 Tentang Pelayaran, (2008). 